\title{
Biochemical Analysis on a Microchip
}

\author{
Stephen C. Jacobson and J. Michael Ramsey \\ Chemical and Analytical Sciences Division \\ Oak Ridge National Laboratory \\ P.O. Box 2008 \\ Oak Ridge, Tennessee 37831-6142
}

\begin{abstract}
A microchip that performs an automated restriction fragment analysis is demonstrated. The device mixes a DNA sample with a restriction enzyme in a $0.7 \mathrm{nl}$ reaction chamber and after a digestion period injects the fragments onto a $67-\mathrm{mm}$ long capillary electrophoresis channel for sizing. Materials are precisely manipulated under computer control within the channel structure using electrokinetic transport. Digestion of the plasmid pBR322 by the enzyme Hinf I and fragment analysis are completed in 5 min using 30 amol of DNA and $2.8 x$ $10^{-3}$ units of enzyme per run.
\end{abstract}

\section{INTRODUCTION}

Important problems in biology and medicine will benefit from the ability to perform automated, rapid, and precise biochemical procedures on minute quantities of material in a highly parallel fashion. There is promise that microfabricated components can be integrated into a single device to solve a complete chemical or biochemical procedures. Simple but powerful examples of integrated devices for performing chemical reactions and separations have been demonstrated using monolithic devices [1-2]. The advantages of integrated devices that perform chemistry and chemical analysis may be quite similar to those realized by the microelectronics industry through the integrated circuit. Potential advantages include low cost, compact devices with high speed processing while improving operational simplicity and reliability and the added benefit of parallel architectures for solving large problems. Moreover, integration of chemical processing and analysis functions allows automated manipulation of samples and reagents at volumes orders of magnitude smaller than is feasible manually or robotically.

Miniaturized devices that have been fabricated primarily involve electrically driven separation techniques including capillary electrophoresis [3-9], synchronized cyclic electrophoresis [10], free-flow electrophoresis [11], open channel electrochromatography [12], and capillary gel electrophoresis [13-15]. Devices that integrate chemical reactions with analysis include capillary electrophoresis with pre- and post-separation derivatization $[1,16]$. These devices have exhibited the features mentioned above. Here, we demonstrate a monolithic integrated device for performing a biochemical analysis procedure.

\section{EXPERIMENTAL SECTION}

The microchips are fabricated from glass substrates using standard photolithographic, wet chemical etching and bonding techniques as previously described [8]. The microchip design is depicted in Figure 1. The reaction chamber and separation column are 1 and $67 \mathrm{~mm}$ long, respectively, having a width at half-depth of $60 \mu \mathrm{m}$ and a depth of $12 \mu \mathrm{m}$; the reaction chamber has a corresponding volume of $0.7 \mathrm{nl}$. The electroosmotic flow is minimized by the covalent immobilization of linear polyacrylamide.

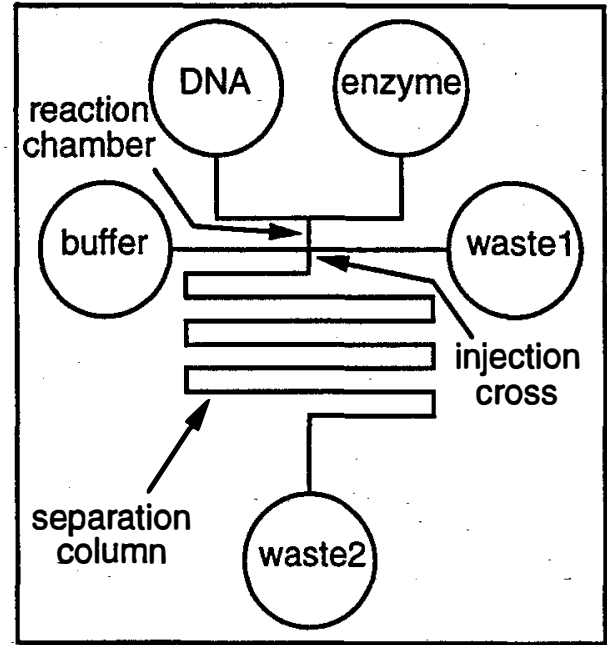

Figure 1. Schematic of a microchip with an integrated pre-column reactor (0.7 $\mathrm{nl}$ volume) and $67-\mathrm{mm}$ serpentine separation column.

Chip performance and separations are monitored using laser induced fluorescence (LIF). The reaction buffer is $10 \mathrm{mM}$ Tris-acetate, $10 \mathrm{mM}$ magnesium acetate, and $50 \mathrm{mM}$ potassium acetate. The reaction buffer is placed in the DNA, enzyme and waste 1 reservoirs (Figure 1). The separation buffer is $9 \mathrm{mM}$ Tris-borate with $0.2 \mathrm{mM}$ EDTA and $1 \%(\mathrm{w} / \mathrm{v})$ hydroxyethyl cellulose. The separation buffer is placed in the buffer and waste 2 reservoirs. The concentrations of the plasmid pBR322 and enzyme Hinf $I$ are $125 \mathrm{ng} / \mu \mathrm{l}$ and 4 units/ $\mu \mathrm{l}$, respectively. The digestions and separations are performed at room temperature $\left(20^{\circ} \mathrm{C}\right)$.

\section{RESULTS AND DISCUSSION}

First, the DNA and enzyme are electrophoretically migrated into the reaction chamber. A voltage is also applied to the buffer reservoir to prevent the DNA and enzyme froni migrating onto the separation column. After the reaction chamber is loaded and is at equilibrium, the digestion can be performed either dynamically with the electric potentials still applied to the chip or statically by removing all electric potentials. To perform the fragment size analysis following digestion, the products are introduced onto the separation 
column by applying a potential between the DNA and enzyme reservoirs and the waste 2 reservoir with potentials at the buffer and waste 1 reservoirs removed for a brief period of time, 1 to 10 s. To break off the injection plug and to perform the electrophoretic separation, the potentials at the buffer and waste 1 reservoirs are reapplied.

The fragments are resolved using $1.0 \%(\mathrm{w} / \mathrm{v})$ hydroxyethyl cellulose as the sieving medium. Figure 2 shows an electropherogram of the restriction fragments of the plasmid pBR322 following a 2 min digestion by the enzyme Hinf I. To enable efficient on-column staining of the double-stranded DNA after digestion but prior to interrogation, the intercalating dye, TOTO-1 $(1 \mu \mathrm{M})$, is placed in the waste 2 reservoir only and migrates countercurrent to the DNA. As expected, the relative intensity of the bands increases with increasing fragment size because more intercalation sites exist in the larger fragments. The unresolved 220/221-bp and 504/517-bp fragments have higher intensities than adjacent single fragment peaks due to the band overlap.

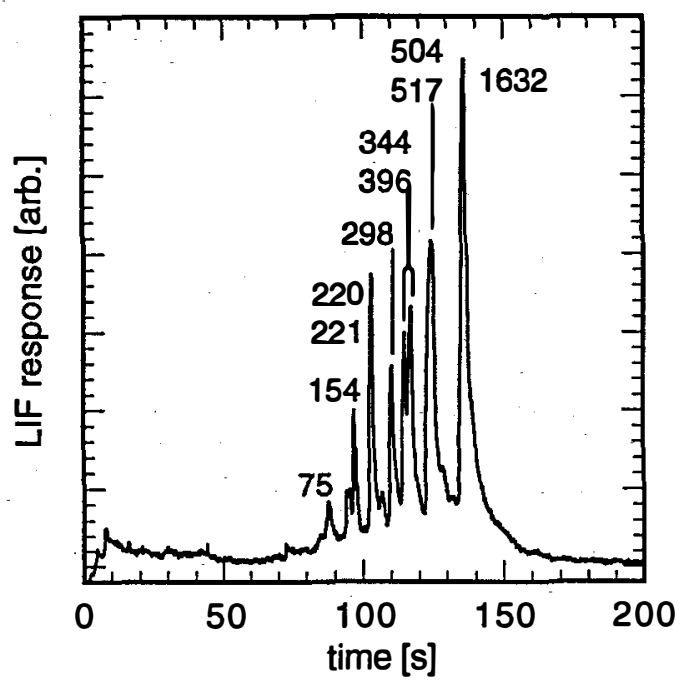

Figure 2. Electropherogram of products from the digestion of the plasmid $p B R 322$ by the enzyme Hinf $I$. The separation field strength is $380 \mathrm{~V} / \mathrm{cm}$, and the separation length is $67 \mathrm{~mm}$. The numbers correspond to the fragment lengths in base pairs.

The digestion times ranged from 9 to $189 \mathrm{~s}$. The 9-s reaction period corresponds to the transit time of the plasmid through the reaction chamber and is the minimum reaction time. For other reaction times, the voltage to the chip is removed to allow digestion to occur. The intensity of the 1632-bp and 504/517-bp fragment peaks increases for reaction times from 9 $\mathrm{s}$ to $129 \mathrm{~s}$ ( 2 min dwell time plus $9 \mathrm{~s}$ transit time) by $\approx 10$ times, but for a $189 \mathrm{~s}$ reaction period ( $3 \mathrm{~min}$ dwell time plus $9 \mathrm{~s}$ transit time), no further increase in fragment yield is observed.

\section{ACKNOWLEDGEMENTS}

This research is sponsored by Oak Ridge National Laboratory (ORNL) Laboratory Directed Research and Development Fund. ORNL is managed by Lockheed Martin Energy Research Corporation for the U.S. Department of Energy under contract DE-AC05-96OR22464.

\section{REFERENCES}

1. S.C. Jacobson, R. Hergenröder, A.W. Moore, Jr., and J.M. Ramsey; "Precolumn Reactions with Electrophoretic Analysis Integrated on a Microchip," Anal. Chem., 66, 4127 (1994).

2. S.C. Jacobson and J.M. Ramsey, "Integrated Microdeivce for DNA Restriction Fragment Analysis," Anal. Chem., 68, 720 (1994).

3. D.J. Harrison, A. Manz, Z. Fan, H. Ludi, and H.M. Widmer, "Capillary Electrophoresis and Sample Injection Systems Integrated on a Planar Glass Chip," Anal. Chem., 64, 1926 (1992).

4. A. Manz, D.J. Harrison, E.M.J. Verpoorte, J.C. Fettinger, A. Paulus, H. Ludi, and H.M. Widmer, "Planar Chips Technology for Miniaturization and Integration of Separation Techniques into Monitoring Systems. Capillary Electrophoresis on a Chip," J. Chromatogr. 593, 253 (1992).

5. D.J. Harrison, K. Fluri, K. Seiler, Z. Fan, C.S. Effenhauser, and A. Manz, "Micromachining a Miniaturized Capillary Electrophoresis-Based Chemical Analysis System on a Chip," Science, 261, 895 (1993).

6. C.S. Effenhauser, A. Manz, and H.M. Widmer, "Glass Chips for High-Speed Capillary Electrophoresis Separations with Submicrometer Plate Heights," Anal. Chem., 65, 2637, 1993.

7. K. Seiler, D.J. Harrison, and A. Manz, "Planar Glass Chips for Capillary Electrophoresis: Repetitive Sample Injection, Quantitation, and Separation Efficiency," Anal. Chem., 65, 1481 (1993).

8. S.C. Jacobson, R. Hergenröder, L.B. Koutny, R.J. Warmack, and J.M. Ramsey, "Effects of Injection Schemes and Column Geometry on the Performance of Microchip Electrophoresis Devices," Anal. Chem., 66, 1107 (1994).

9. S.C. Jacobson, R. Hergenröder, L.B. Koutny, and J.M. Ramsey, "High Speed Separations on a Microchip," Anal. Chem., 66, 1114 (1994).

10. N. Burggraf, A. Manz, C.S. Effenhauser, E. Verpoorte, N.F. de Rooij, and H.M. Widmer, "Synchronized Cyclic Capillary Electrophoresis - A Novel Approach to Ion Separations in Solution," J. High Res. Chromatogr., 16, 594 (1993).

11. D.E. Raymond, A. Manz, and H.M. Widmer, "Continuous Sample Pretreatment Using a Free-Flow Electrophoresis Device Integrated onto a Silicon Chip," Anal. Chem., 66, 2858 (1994). 12. S.C. Jacobson, R. Hergenröder, L.B. Koutny, and J.M. Ramsey, "Open Channel Electrochromatography on a Microchip," Anal. Chem., 66, 2369 (1994).

13. C.S. Effenhauser, A. Paulus, A. Manz, and H.M. Widmer, "High-Speed Separation of Antisense Oligonucleotides on a Micromachined Capillary Electrophoresis Device," Anal. Chem., 66, 2949 (1994).

14. A.T. Woolley and R.A. Mathies, "Ultra-High-Speed DNA Fragments Separations. Using Microfabricated Capillary Array Electrophoresis Chips," Proc. Natl. Acad. Sci. USA, 91, 11348 (1994).

15. A.T. Woolley and R.A. Mathies, "Ultra-High-Speed DNA Fragments Separations Using Microfabricated Capillary Array Electrophoresis. Chips," Anal. Chem., 67, 3676 (1995).

16. S.C. Jacobson, L.B. Koutny, R. Hergenröder, A.W. Moore, Jr., and J.M. Ramsey, "Microchip Capillary Electrophoresis with an Integrated Postcolumn Reactor," Anal. Chem., 66, 3472 (1994). 